\title{
HUBUNGAN KARAKTERISTIK INDIVIDU DENGAN NILAI AMBANG DENGARTENAGA KERJA (Studi Pada Ruang Produksi PT. Ispat Wire Products Sidoarjo)
}

\author{
Oktavia Dwi Savitri, Erna Triastuti, SB. Eko Warno
}

\begin{abstract}
ABSTRACK
PT. Ispat Wire Products is a company that utilizes various machines in its operation and generate high level of noise intensity. This situation may eventually affect the health of workers, especially in relation to the hearing threshold value. Therefore it is necessary to launch an investigative inquiries on the relationship of individual's characteristics such as age, years of service and use of hearing protection devices with the threshold hearing among noise-exposed workers.

This type of analytical study involved with a sample of 60 workers. Sampling was done by simple random sampling, while the chi-square test was used in the analysis to determine the relationship of individual's characteristics with the threshold hearing level among noise-exposed workers using.

Measurements resulted in an average noise intensity of 96.8 dBA. The measured threshold value exceeded the specified figure designated in the Minister of Manpower Decree No. 51/Men/1999, which designated a value of $85 \mathrm{dBA}$ for 8 hours/day or 40 hours/week. Results of the chi-square test proved the relationship between individual's characteristics including age, years of service and usage of PPD with hearing threshold among noise-exposed workers.

Therefore, it was recommended that the company should initiate both noise control engineering and administrative measures, and set local regulation designating penalties against workers who violated the provisions of the company.
\end{abstract}

Keywords : Individual characteristics, hearing threshold, machineries, high noise intensity, noiseexposed workers

\section{PENDAHULUAN}

Pertumbuhan industri yang sangat pesat tanpa disertai dengan upaya pengamanan efek samping penerapan teknologi akan menimbulkan berbagai masalah kesehatan dan keselamatan kerja, dapat meningkatkan prevalensi penyakit akibat kerja, keracunan, cacat dan bahkan kematian.

Dalam kegiatan industri penggunaan teknologi modern sangat diperlukan untuk meningkatkan hasil produksinya.Keberadaan mesin dan peralatan produksi dapat menghasilkan barangbarang yang bermanfaat bagi kesejahteraan masyarakat dalam jumlah yang banyak dan waktu yang singkat. Penggunaan mesin dan perlatan produksi tersebut juga akan menghasilkan bahanbahan buangan dan meningkatkan risiko bahaya kerja, termasuk bahaya terhadap keselamatan dan kesehatan tenaga kerja. Salah satu efek yang ditimbulkan dari penggunaan mesin - mesin dalam industri yaitu kebisingan.

Kebisingan adalah suara yang tidak dikehendaki bersumber dari alat - alat proses produksi atau alat alat kerja yang pada tingkat tertentu sehingga dapat menimbulkan gangguan kesehatan. Menurut Keputusan Menteri Tenaga Kerja No. 51/MEN/1999 tentang Nilai Ambang Batas (NAB) kebisingan yang ditetapkan adalah 85 dBA untuk waktu kerja yang tidak lebih dari 8 jam / hari atau 40 jam / minggu. Bila terjadi kebisingan melebihi NAB yang telah ditentukan maka akan berdampak pada gangguan pendengaran dan gangguan non pendengaran bagi tenaga kerja yang terpapar bising.

PT. Ispat Wire Products merupakan produsen nails terbesar di Indonesia yang didirikan pada tahun 1991 dengan beberapa jenis produk. Beberapa produk diantaranya adalah Straight Bars (billet batang lurus), nails (paku), wire mesh dan mebel. Dalam proses produksi meliputi drawing, nail dan STMC (straightening machine) telah menggunakan mesin sebanyak 110 unit. Hasil pengukuran pada bulan November, mesin - mesin tersebut menghasilkan intensitas kebisingan $93-96 \mathrm{dBA}$, yang berarti intensitas kebisingan berada diatas NAB berdasarkan peraturan yang ditetapkan. Keadaan ini berpengaruh terhadap kesehatan tenaga kerja terutama terhadap ambang pendengarannya.

\section{METODE PENELITIAN \\ Jenis Penelitian}

Penelitian ini termasuk penelitian analitik secara observasional dimana memberikan gambaran secara sistematis berdasarkan fakta yang diperoleh di lapangan dengan mengumpulkan data, pengukuran serta menjelaskan suatu masalah yang ingin dipecahkan dan menganalisanya.

\section{Objek Penelitian}

Besar Sampel yang diambil 60 tenaga kerja dari populasi 70 tenaga kerja di Bagian Produksi PT. IWP 
Variabel Penelitian

a. Variabel bebas yaitu variabel yang mempengaruhi variabel terikat. Dalam penelitian ini adalah, umur, masa kerja, dan pemakaian APT.

b. Variabel terikat yaitu variabel yang terjadi karena pengaruh variabel bebas.Dalam penelitian ini adalah nilai ambang dengar pada tenaga kerja yang terpapar bising.

\section{Analisis Data}

Penyajian hasil penelitian dibuat dalam bentuk tabulasi dan dianalisis secara statistik dengan uji chi-square.

\section{HASIL PENELITIAN DAN PEMBAHASAN}

\section{Umur}

Tabel 1

Hubungan Antara Umur Dengan Nilai Ambang dengar Tenaga Kerja di PT. Ispat Wire Products

\begin{tabular}{|c|c|c|c|c|c|c|c|}
\hline \multirow{2}{*}{ Umur } & \multicolumn{3}{|c|}{ Nilai Ambang Dengar } & \multicolumn{2}{c|}{ Total } & \multirow{2}{*}{ P } \\
\cline { 2 - 7 } & \multicolumn{2}{|c|}{ Normal } & Tidak Normal & \multicolumn{2}{c|}{ Frek } & $\%$ & \\
\cline { 2 - 7 } & Frek & $\%$ & Frek & $\%$ & & F \\
\hline $\begin{array}{c}\text { Kurang dari } \\
40 \text { tahun }\end{array}$ & 12 & 75 & 4 & 25 & 16 & 100 & \multirow{2}{*}{0,008} \\
\hline $\begin{array}{c}\text { Lebih dari sama dengan 40 } \\
\text { tahun }\end{array}$ & 16 & 36,4 & 28 & 63,3 & 44 & 100 & \\
\hline
\end{tabular}

Dari tabel 1 dapat diketahui bahwa tenaga kerja yang berumur lebih dari 40 tahun dan memiliki nilai ambang dengar normal adalah sebanyak 12 orang $(75 \%)$, sedangkan tenaga kerja yang berumur kurang dari sama dengan 40 tahun dan memiliki nilai ambang dengar tidak normal adalah sebanyak 28 orang $(63,3 \%)$.

Dari uji Chi-Square, didapatkan nilai P 0,008 $\leq$ 0,05 artinya ada hubungan antara masa kerja dengan nilai ambang dengar.Hal tersebut menunjukkan bahwa semakain bertambah umur, maka semakin meningkat nilai ambang dengarnya. Nilai ambang dengar yang semakin meningkat menujukkan bahwa kemampuan mendengar semakin menurun. Menurut Sihar Tigor B.T, sensitivitas (kecepatan bereaksi) dan mekanisme pertahanan (Protection mechanism) sistem pendengaran manusia umunya akan berkurang seiring bertambahnya umur. Berkurangnya sensitivitas sistem pendengaran manusia, terutama terhadap suara-suara berfrekuensi tinggi, seiring bertambahnya umur membuat sebagian dari sel -sel rambut yang terdapat di telinga bagian dalam akan mati karena tua atau biasa disebut dengan presbycusis.

\section{Masa Kerja}

Tabel 2

Hubungan Antara Masa Kerja dengan Nilai Ambang dengar Tenaga Kerja di PT. Ispat Wire Products

\begin{tabular}{|c|c|c|c|c|c|c|c|}
\hline \multirow{3}{*}{ Masa kerja } & \multicolumn{4}{|c|}{ Nilai Ambang Dengar } & \multirow{2}{*}{\multicolumn{2}{|c|}{ Total }} & \multirow{3}{*}{$\mathbf{P}$} \\
\hline & \multicolumn{2}{|c|}{ Normal } & \multicolumn{2}{|c|}{ Tidak Normal } & & & \\
\hline & Frek & $\%$ & Frek & $\%$ & Frek & $\%$ & \\
\hline Kurang dari sama dengan 10 tahun & 12 & 70,6 & 5 & 29,4 & 17 & 100 & \\
\hline Lebih dari 10 tahun & 16 & 37,2 & 27 & 62,8 & 43 & 100 & 0,02 \\
\hline
\end{tabular}

Dari tabel 2 dapat diketahui bahwa tenaga kerja yang bekerja kurang dari sama dengan 10 tahun dan memiliki nilai ambang pendengaran normal adalah sebanyak 12 orang $(70,6 \%)$, sedangkan tenaga kerja yang bekerja lebih dari 10 Tahun dan memiliki nilai ambang pendengaran tidak normal adalah sebanyak 27 orang $(62,8 \%)$.

Dari uji Chi-Square, didapatkan nilai $\mathrm{P} 0,02 \leq 0,05$ artinya ada hubungan antara masa kerja dengan nilai ambang dengar. Hal tersebut menunjukkan bahwa semakin lama masa kerja tenaga kerja terpapar bising, maka semakin meningkat nilai ambang dengarnya. Menurut Siswanto, ketulian permanen yang umumnya terjadi setelah pemaparan 10 tahun atau lebih dan kenaikan nilai ambang dengar tersebut terjadi secara perlahan lahan, maka biasanya penderita tidak menyadari dirinya telah menderita ketulian. Untuk tenaga kerja pada Bagian Produksi PT. Ispat Wire Products yang memiliki masa kerja 10 tahun, berarti kemungkinan besar telah terpapar bising dalam jangka waktu yang lama dan terus menerus sehingga dapat mengalami ketulian sementara yang apabila dibiarkan maka akan menjadi ketulian secara permanen. 


\section{Pemakaian APT}

Tabel 3

Hubungan Antara Pemakaian APT dengan Nilai Ambang dengar Tenaga Kerja di PT. Ispat Wire Products

\begin{tabular}{|c|c|c|c|c|c|c|c|}
\hline \multirow{3}{*}{ Pemakaian APT } & \multicolumn{4}{|c|}{ Nilai Ambang Dengar } & \multirow{2}{*}{\multicolumn{2}{|c|}{ Total }} & \multirow{3}{*}{$\mathbf{P}$} \\
\hline & \multicolumn{2}{|c|}{ Normal } & \multicolumn{2}{|c|}{ Tidak Normal } & & & \\
\hline & Frek & $\%$ & Frek & $\%$ & Frek & $\%$ & \\
\hline Selalu Memakai & 20 & 58,8 & 14 & 41,2 & 34 & 100 & \multirow{2}{*}{0,031} \\
\hline Jarang Memakai & 8 & 30,8 & 18 & 69,2 & 26 & 100 & \\
\hline
\end{tabular}

Dari tabel 3 dapat diketahui bahwa dari 34 tenaga kerja yang memakai APT, dan memiliki nilai ambang dengar normal adalah sebanyak 20 orang $(58,8 \%)$, sedangkan dari 26 tenaga kerja yang jarang memakai APT, dan memiliki nilai ambang dengar tidak normal adalah sebanyak 18 orang $(69,2 \%)$.

Dari uji Chi-Square, didapatkan nilai P 0,031 $\leq$ 0,05 artinya ada hubungan antara pemakaian APT dengan nilai ambang dengar.Hal tersebut dikarenakan, daerah utama kerusakan akibat kebisingan pada manusia adalah pendengaran (telinga bagian dalam), maka upaya pengendalian dengan memanfaatkan alat bantu yang bisa mereduksi tingkat kebisingan yang masuk ke bagian telinga bagian luar dan bagian tengah sebelum masuk ke telinga bagian dalam.

\section{DAFTAR PUSTAKA}

Anizar.2009. Teknik Keselamatan dan Kesehatan Kerja Di Industri. Yogyakarta: Graha Iimu.

Darmawan, Very. 2013. Hubungan Antara Karakteristik Individu Dengan Nilai Ambang Dengar Pada Tenaga Kerja PT. Bangun Sarana Baja Gresik (Studi Di Gudang 4 Dan 5 Pt Bangun Sarana Baja). Surabaya: Program Pasca Sarjana Universitas Airlangga Surabaya.

Depkes RI Pusat Kesker. 2003. Modul Pelatihan Bagi Fasilitator Kesehatan Kerja. Jakarta.

Djojodibroto, Darmanto. 1999. Kesehatan Kerja di Perusahaan. Jakarta: PT Gramedia Pustaka Utama.

Keputusan Menteri Tenaga Kerja Nomor : Kep51/Men/1999 Tentang Nilai

Ambang Batas Faktor Fisika Di Tempat Kerja.

Nazar, Moh. 2003. Metode Penelitian. Jakarta: Ghalia Indonesia

Notoatmodjo, Soekidjo. 2010. Metodologi Penelitian Kesehatan. Jakarta: PT Rineka Cipta.

PK,Suma'mur. 2009. Higiene Perusahaan dan Keselamatan Kerja (HIPERKES). Jakarta: Sagung Seto.

Ridley, John. 2004. Kesehatan dan Keselamatan Kerja Ikhtisar Edisi Ketiga. Jakarta: Ciracas

Santoso, Gempur. 2004. Manajemen Keselamatan \& Kesehatan Kerja.Jakarta: Prestasi Pustaka Publisher.

\section{KESIMPULAN}

Ada hubungan antara umur, masa kerja dan pemakaian APT tenaga kerja dengan nilai ambang dengar.

\section{SARAN}

1. Pemasangan safety poster / sign board di lingkungan kerjapada saat memasuki kawasan bising untuk wajib menggunakan APT.

2. Mengadakan beberapa shift bagi tenaga kerja yang terpapar bising untuk mengurangi jam kerja.

3. Sebaiknya dilakukan upaya pengendalian secara teknik seperti pemasangan peredam suara pada langit - langit, dinding dan lantai di Bagian Produksi PT. Ispat Wire Products.

Santoso, Singgih. 2013. Menguasai SPSS 21 Di Era Informasi. Jakarta: PT Elex Media Komputindo.

Siswanto, A. 1991. Kebisingan. Surabaya: Balai Hiperkes dan Keselamatan Kerja. Jawa Timur.

Suardi, Rudi. 2007. Sistem Manajemen Keselamatan Dan Kesehatan Kerja. Jakarta: Penerbit PPM.

Subana, M. Rahadi, dan Sudrajat. 2000. Statistik Pendidikan. Bandung: CV. Pustaka Setia

Sugeng, B. 2003. Higiene Perusahaan Dan Keselamatan Kerja Di Industri. Yogyakarta: Graha IImu.

Surya, Turmaningsih. 2010. Analisis Hubungan Umur Dan Lama Pemajanan Dengan Daya Dengar Berdasarkan Hasil Pemeriksaan Audiometri Tenaga Kerja Di Unit Produksi Central Processing Area JOB P-PEJ Tuban Jawa Timur.Surakarta: Program D.IV Kesehatan Kerja Universitas Sebelas Maret. http://

eprints.uns.ac.id/8129/1/14441130820100 9471.pdf. 10 Januari 2014

Tambunan, Sihar T B. 2005. Kebisingan Di Tempat Kerja. Yogyakarta: CV Andi Offseti.

Triwibowo, Cecep, Mitha Erlisya Pusphandani. 2013. Kesehatan Lingkungan Dan K3. Yogyakarta: Medika.

Winarsono, Tulus. 2008. Psikologi Keselamatan Kerja. Malang: UMM PRESS. 